\title{
Kutatómunka a BME Fizikai Kémia és Anyagtudományi Tanszékén
}

\author{
KÁLLAY-MENYHÁRD Alfréd, KIRSCHWENG Balázs, HÁRI József, POLYÁK Péter, \\ LÁSZLÓ Krisztina, HÓRVÖLGYI Zoltán, ALBERT Emőke, KUBINYI Miklós, \\ GYARMATI Benjámin, SZILÁGYI András, KÁLLAY Mihály*
}

BME Fizikai Kémia és Anyagtudományi Tanszék, Müegyetem rkp. 3., 1111 Budapest

\section{Bevezetés}

A BME Fizikai Kémia és Anyagtudományi Tanszéke (FKAT) 2007. január 1-én jött létre az 1951 óta müködő Fizikai Kémia és az 1953-ban alapított Műanyag- és Gumiipari Tanszék egyesítésével. A Tanszék munkatársai a felületkémia, a kolloidika, a polimerkémia, az anyagtudomány, a spektroszkópia és az elméleti kémia területein végeznek kutatásokat. Ebben a közleményben áttekintjük a Tanszék csoportjainak kutatási irányait és az elmúlt évek főbb eredményeit.

\section{Felületkémiai Csoport}

A csoport kutatási tevékenységének középpontjában hagyományosan a nagyfelületü szilárd anyagok adszorpcióhoz köthető viselkedése áll. Maga a jelenség régóta ismert, számtalan gáz és folyadékfázisok elválasztására, tisztítására alkalmazott eljárás alapja. Jelentősége pl. az analitikában, az élelmiszeriparban vagy a környezet- védelemben önmagáért beszél. Innovatív, anyagtudományi kutatásaink célja kiemelkedő szorpciós tulajdonságú új anyagok előállítása és alkalmazási területeik feltárása, ill. a szorpció és más, a felhasználás szempontjából releváns tulajdonságok kombinálása, akár társított rendszerekben is ${ }^{1}$. Az adszorpció az anyagok felületéhez kapcsolódó tulajdonság. Fajlagosan nagy felületü anyagok a nanorészecskék és a pórusosrendszerek. A Felületkémiai Csoportban kristályos szén nanorészecskékkel (nanocsö ${ }^{2}$, grafén ${ }^{3,4}$ és származékaik) és pórusos széngélekkel ${ }^{5}$ egyaránt foglalkozunk, nemzetközi együttmüködésben is. Az utóbbi időben fordultunk a fémorganikus térhálók felé, melyeket jelenleg az adszorpciós gáztárolás legígéretesebb anyagaiként tartanak számon ${ }^{6}$.

A mezopórusos szénaerogélek a pórusos szenek különleges tulajdonságokkal bíró családját alkotják, pl. egyszerre hőszigetelők és elektromos vezetők. Nagy fajlagos felületük tág, könnyen átjárható pórusokkal párosul, ami áramló közegben és biológiai alkalmazásokban is előnyös. Az első széngél prekurzort 1989-ben Pekala állította elő rezorcinból és formaldehidből ${ }^{7}$. A széngélek nagy előnye abban rejlik, hogy morfológiájuk és felületkémiájuk az alkalmazási területnek megfelelően tervezhető. Az elöállításuk során gyakran alkalmazott szol-gél technika további elönye, hogy a szintézis bármely pontján vagy utókezeléssel könnyen építhetők be heteroatomok (pl. átmeneti fémek ${ }^{8}$, kén $^{9}$, nitrogén ${ }^{10}$, stb.).
A szénmátrixba juttatott nitrogén az elektrontöbblet révén már kis mennyiségben is kedvezően befolyásolja a szenek tulajdonságait. A rezorcin mellett felhasznált melaminko-monomer sztöchiometrikus beépülése révén hangolható módon, 1-4 \% nitrogén tartalmú széngélt tudtunk előállítani, mely a nitrogént döntően piridines, un. N6 (2) formában tartalmazza.

Vízgőzadszorpciós vizsgálatokkal megállapítottuk, hogy a heteroatom ( $\mathrm{O}$ és $\mathrm{N}$ ) tartalom javítja a szénfelület hidrofilitását. A módosított felületkémiájú széngélek egyik legintenzívebben kutatott alkalmazási területe az energiatárolás ${ }^{11}$ és konverzió, a nitrogén ugyanis növeli a szenek aktivitását pl. a protoncsere-membrános üzemanyag-cellák katódján lejátszódó oxigén redukciós reakcióban (ORR). Ciklikus voltammetriás vizsgálataink megerősítették, hogy a szenek nitrogén tartalma szignifikánsan növeli azok ORR aktivitását (1. ábra).

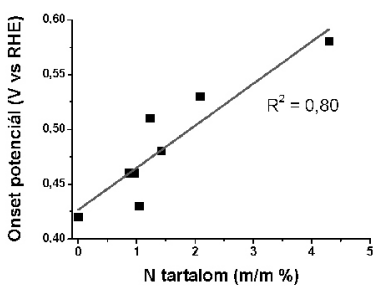

a

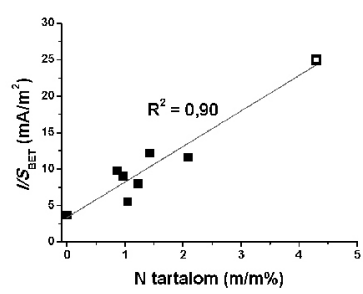

b
1. ábra: A ciklikus voltammetriás görbék ún. on-set potenciálja (a) és a szén elektród látszólagos felületére normált katódos csereáramsürüsége (b) a tömbfázisbeli nitrogéntartalom függvényében ${ }^{10}$

A 1.b ábrán látható közel lineáris kapcsolat azt mutatja, hogy a nitrogén hozzáférhetőségének, azaz a szén fajlagos felületének fontos szerepe van a vizsgált elektrokémiai folyamatban. Hasonló módon szintetizált, de grafén-oxidot is tartalmazó szén aerogélből készült elektródunkat eredményesen alkalmaztuk mikrobiológiai üzemanyagcellában is ${ }^{12}$.

\section{Kolloidkémia Csoport}

A Kolloidkémiai Csoport érdeklődési körében kiemelt szerepet kap a különböző típusú vékonyrétegek fejlesztése és jellemzése. 
Különböző módokon előállított, ezüsttartalmú mezopórusos $\mathrm{TiO}_{2}$ szol-gél bevonatok antibakteriális hatását hasonlítottuk össze. A vizsgálatokhoz Escherichia coli baktériumtörzset használtunk. Emellett vizsgáltuk az ezüstadalék jellegének és mennyiségének, valamint a kompozit bevonat szerkezeti jellemzőinek az antibakteriális tulajdonság időtállóságára kifejtett hatását. Megállapítottuk, hogy a bevonatok látható fényben és sötétben egyaránt hatásosak. Kimutattuk, hogy a minták jelentős antibakteriális hatását a bevonatból kilépő ezüst mennyisége határozza meg, a $\mathrm{TiO}_{2}$-bevonatok fotokatalitikus aktivitásának hatása a baktériumokra emellett elhanyagolható. Kimutattuk, hogy a mezopórusos bevonatok impregnálásával megfelelö mennyiségű ezüst juttatható a pórusok belsejébe az antibakteriális hatás biztosításához. ${ }^{12,13,14}$

Mezopórusos, félvezető anyagú $\left(\mathrm{TiO}_{2}, \mathrm{ZnO}\right)$ bevonatok összetételét, kristályosságát, pórusszerkezetét szabályozva vizsgáltuk a fotoaktív tulajdonságok változását, melyhez modellszínezék fotodegradációját követtük nyomon optikai spektroszkópiai módszerekkel. Különböző módszerekkel állítottunk elő nemesfémekkel (arany, ezüst) adalékolt $\mathrm{TiO}_{2}$-bevonatokat, melyek megnövekedett fotoaktivitást mutattak. Különböző színezékeket adszorbeálva a bevonatok pórusrendszerében, majd a színezékek fotodegradációját a szilárd-levegő határfelületen tanulmányozva UV és látható fényü megvilágítás mellett, információkat szereztünk a színezék-félvezető kölcsönhatásokról (színezék-érzékenyítés), a színezékek bomlási folyamatairól (sebesség, kinetika), valamint fotostabilitásáról. Kimutattuk, hogy a bevonatok pórusrendszerében adszorbeált színezékek mennyisége, ill. az asszociált formák-monomerek mennyiségének aránya szabályozható a bevonatok impregnálása során alkalmazott színezékoldat pH-jának, koncentrációjának, az alkalmazott oldószernek megválasztásával.

Különböző típusú, kompakt és mezopórusos $\mathrm{SiO}_{2}-$ bevonatok esetén az előállítási paramétereknek a bevonatok permeabilitására gyakorolt hatását tanulmányoztuk. A $130-350 \mathrm{~nm}$ vastagságú bevonatokat Zn-felületeken alakítottuk ki. A korróziógátló hatás növelésére a bevonatok felületét monofunkciós vagy bifunkciós szililezőszerekkel hidrofobizáltuk. Azt tapasztaltuk, hogy a mezopórusos bevonatok szigetelő hatása eléri a kompakt szilika bevonatokét, mely számottevő korróziót gátló hatásban is megmutatkozik. Kimutattuk, hogy a felületi hidrofobizálás eredményeképpen a korróziós áramsürüségértékek egy, vagy két nagyságrenddel csökkentek a nem hidrofobizált rétegeknél mért értékekhez képest. Kidolgoztunk egy új eljárást, mely lehetővé teszi különböző korróziós inhibitoranyagok tárolását mezopórusos $\mathrm{SiO}_{2}$ bevonatokban. Ennek során a pórusrendszerbe impregnálással bejuttatott modellinhibitort a bevonat felületi hidrofobizálásával zártuk el a külvilágtól, ezáltal biztosítva, hogy a bevonatokból vizes közegben csak a bevonatok sérülése esetén áramolhasson ki a hatóanyag, mely ily módon öngyógyító hatást eredményezhet. ${ }^{12,13,15,16}$

Fényáteresztést növelő bevonatok fejlesztése céljából mezopórusos $\mathrm{SiO}_{2}$ szol-gél vékonyrétegeket képeztünk üveg- és polikarbonát-hordozókon. Spektroszkópiai ellipszometria, illetve ellipszometriai porozimetria vizsgálatokkal a bevonatok vastagságát 85 - 135 nm, porozitásukat pedig 18 - 37\%-nak találtuk. A bevonatok pórusrendszere zsugorodásának megakadályozása céljából sav-, vagy báziskatalizált vázerősítési eljárást alkalmaztunk. A minták időbeli, optikai stabilitását UV-Vis spektrometriával tanulmányozva megállapítottuk, hogy a minták elönyös optikai tulajdonságaikat $\left(\mathrm{T}_{\max }=98 \%-99 \%\right)$ akár 1 év tárolási idő után is megőrizték. ${ }^{17}$

Szabályozott hatóanyagleadás modelljeként kitozán és kétrétegü - Rodamin 6G színezékkel impregnált mezopórusos $\mathrm{SiO}_{2}$-kitozán (300 - 3000 nm vastagságú) vékonyrétegeket alakítottunk ki üveghordozók felületén. A natív, illetve ionosan és kovalensen térhálósított kitozánbevonatok tulajdonságait 7,3-as pH-jú vizes közegben tanulmányoztuk. Spektroszkópiai ellipszometriával kimutattuk, hogy a kitozánréteg natív állapotához képest a kovalens térhálósítás kisebb, míg az ionos térhálósítás nagyobb duzzadási fokot eredményezett. A térhálósított kitozánbevonatok - a duzzadási viselkedéstől függetlenül - jelentős színezékleadást gátló hatást mutattak a vizsgált rendszerekben. ${ }^{18}$

\section{Lágy Anyagok Kutatócsoport}

A csoport fő tevékenységi köre lágy anyagok szintézisére, jellemzésére és ezek lehetséges alkalmazására irányul. Nagy tapasztalattal rendelkezünk intelligens polimerek és polimer gélek fejlesztésében, különös tekintettel a biokompatibilis, szabályozott hatóanyag-leadásra képes rendszerekre, amelyek a környezeti paraméterek (hőmérséklet, $\mathrm{pH}$, fény, mágneses tér stb.) változására érzékenyen és egyértelmü válaszreakcióval reagálnak. Az előállított polimerek és gélek termikus, mechanikai és reológiai tulajdonságainak jellemzésére magas színvonalú műszerpark és szakértelem áll rendelkezésre.

A Lágy Anyagok Kutatócsoport által intenzíven vizsgált polimer család különlegessége, hogy a polimer láncok szintetikusan előállított poliaminosavból - poliaszparaginsav - vagy származékaiból épülnek fel, amely várhatóan biztosítja a biokompatibilitást és biológiai lebonthatóságot. Ezen kedvező tulajdonságok lehetővé teszik a rendszerek humánbiológiai alkalmazását, elsősorban a hatóanyagleadás területén. A csoport által előállított változatos kémiai szerkezetü polimerek és gélek minden esetben a szervezetben előforduló egy vagy több fiziológiás paraméter megváltozására képesek reagálni ( $\mathrm{pl}$.: pH-gradiens a gasztrointesztinális rendszerben, ${ }^{19}$ redox környezet változása az extra- és intracelluláris tér között ${ }^{20}$ ), amely szelektív hatóanyag-leadást tesz lehetővé, növelve ezzel a terápiás hatékonyságot. A biohasznosulást elnyújtott hatóanyag-leadást biztosító, bioadhezív készítményekkel tervezzük elérni. Számos különböző gyógyszerformát állítunk elő az alkalmazási területnek megfelelően, így vízben duzzadó hidrogéleket, ${ }^{21}$ in situ gélesedő polimer oldatokat (2. ábra), ${ }^{22}$ vízben oldódó polimer filmeket. Elektrosztatikus szálképzéssel, többek között, nagy fajlagos felületü, gyorsan oldódó mátrixokat hozunk létre. Vizsgáljuk a 3D nyomtatás alkalmazási lehetőségeit is fotopolimerizációval előállítható térhálós rendszerek és hidrogélek szintézisében. 
a)
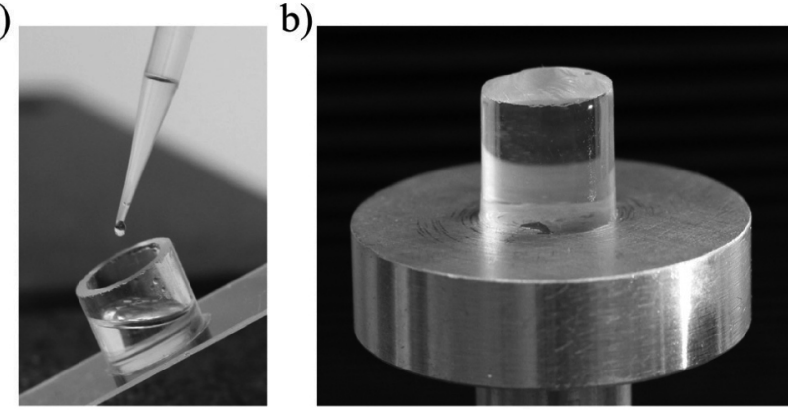

2. ábra: Oxidációra érzékeny poliaminosav-származék (a) kis viszkozitású vizes oldata és az abból (b) in situ előállítható hidrogél ${ }^{22}$

\section{Spektroszkópia Csoport}

A fluoreszcenciás képalkotó módszerek napjainkban gyorsan fejlődnek, s ennek részeként az új fluoreszcens jelzőanyagok fejlesztése ma a kémiai kutatásnak fontos területe. Az FKAT Spektroszkópia Csoportjában az 1990-es évek elején indult el a fluoreszcens jelzőanyagok kutatása. Vizsgálataink során stacionárius és időfelbontásos (időkorrelált egy-foton számlálás, lézeres villanófény fotolízis) spektroszkópiai kísérleteket végzünk. Az új anyagok tervezéséhez és a kísérleti eredmények értékeléséhez elméleti kémiai számításokat végzünk.

Kutatásaink során protikus oldószerekben tanulmányoztuk „charge transfer” típusú fluoreszcens indikátorok tulajdonságait. Protikus közegben, a gerjesztett indikátorban megváltozó lokális töltések miatt változnak az indikátor és az oldószer közötti hidrogénhidak, előfordul, hogy a gerjesztett állapotú festék protonálódik, vagy protont disszociál. Az 5-ciano-N-metilindolin esetében igazoltuk, hogy a cianocsoport és a protikus oldószerek között hidrogénkötés alakul ki, amely gerjesztett állapotban is stabil. ${ }^{23}$ A jelenség kioltást okoz, ami a lokális víztartalom fluoreszcenciás kimutatására ad lehetőséget. A níluskék, az oxazin 720 és a kumarin 102 esetében a sav-bázis tulajdonságok változását vizsgáltuk gerjesztett állapotban. ${ }^{24,25}$ Meghatároztuk a gerjesztett állapotú $\mathrm{pK}_{\mathrm{a}}$ értéket, és a gerjesztett festék és az oldószer közötti protontranszfer sebességét.

Az alkalmazások során figyelembe kell vennünk a jelzőanyagok aggregációját, ami többek között felületeken és pórusokban fordul elö, nagy lokális töltéssürüség hatására. Az ilyen speciális környezeteket modellezhetjük ionos makrociklusokkal, amelyek a jelzőanyaggal szupramolekuláris komplexet képeznek. Mi a kationos festékanyagoknak (oxazin 1, metilénkék) szulfo-kalixarénekkel alkotott komplexeit vizsgáltuk. ${ }^{26,27}$
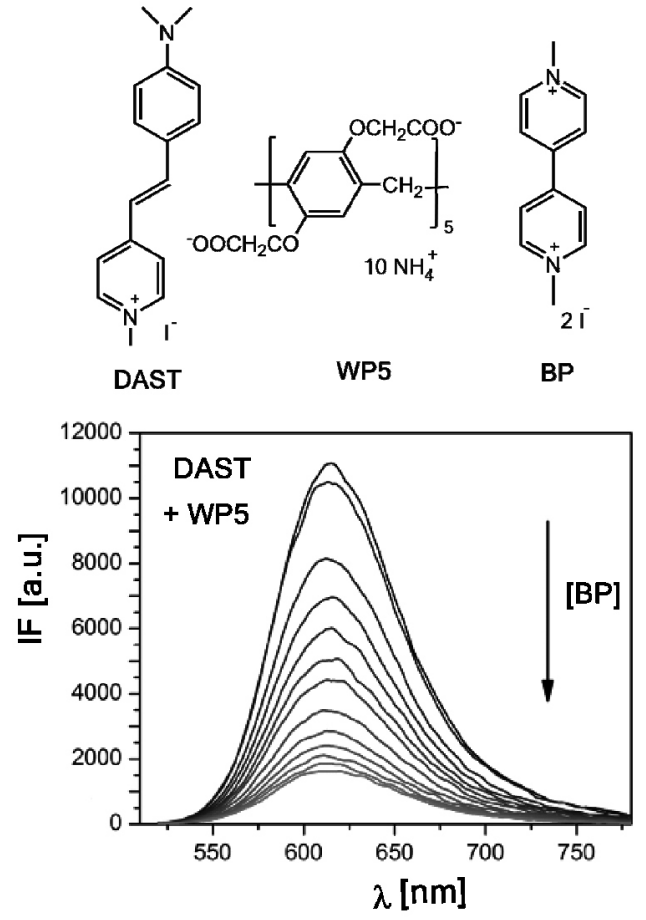

3. ábra: Bipiridinium (BP) fluoreszcenciás kimutatása DAST-WP5 komplexszel. Koncentrációk: $[\mathrm{DAST}]_{0}=5 \mu \mathrm{M},[\mathrm{WP} 5]_{0}=15 \mu \mathrm{M},[\mathrm{BP}]_{0}=$ $0-30 \mu \mathrm{M} . \lambda_{\text {ex }}=506 \mathrm{~nm}$.

A festékmolekulák makrociklussal képzett komplexeit alkalmazzák az analitikai kémiában, nem-fluoreszcens anyagok fluoreszcenciás kimutatására. Az ilyen fluoreszcens szenzorok hasonlóan működnek, mint a bioanalitikában elterjedt kompeticiós assay-k: a makrociklussal, mint receptorral a festék és az analit is komplexet képez. A fluoreszcenciaszínképből megállapítható a szabad és a receptorhoz kötött festék aránya, amiből az analit koncentrációjára következtethetünk. Az utóbbi időben pillérarének - új típusú makrociklusok komplexképzését tanulmányozzuk többféle fluoreszcens jelzőanyaggal, kitérve a képződő komplexek analitikai alkalmazásaira. Stilbazólium festék - pillérarén komplexeinkkel bipiridil vegyületet (3. ábra), ${ }^{28}$ aminokat és bázikus aminosavakat ${ }^{29}$ detektáltunk. A DSS anionos dapoxil festéknek az ammónium pillér[6]arénnel alkotott komplexével ATP-t sikerült kimutatni, a hatás más nukleotiddal szemben szelektívnek bizonyult. ${ }^{30}$

Szintetikus kémikus együttmüködő partnereink számos olyan kémiai szenzort is elöállítanak, amelyekben a fluoreszcens jelzőcsoport kovalensen kapcsolódik az analitot felismerő makrociklushoz. Közülük itt az enantiomereket megkülönböztető királis receptorokat említjük meg. Kutatásaink során királis kalixarének, ${ }^{31}$

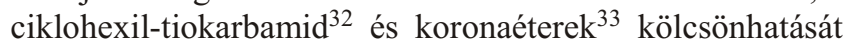
vizsgáltuk királis aminokkal és aminosavakkal. 


\section{Múanyag- és Gumiipari Laboratórium}

A Fizikai Kémia és Anyagtudományi Tanszék részét képező Mủanyag- és Gumiipari Laboratórium (MGL, korábban önálló tanszék) 1953-ban alakult azzal a céllal, hogy a müanyagok előállításában, feldolgozásában és alkalmazásában jártas szakembereket képezzen és ezek a célok a mai napig változatlanok. A kutatócsoport sok változáson esett át és jelen formájában az MGL a Magyar Tudományos Akadémia Természettudományi Kutatóközpontjának (MTA TTK) Polimer Fizikai Osztályával képez egy professzionális kutatócsoportot (továbbiakban Laboratórium).

A jelenlegi kutatásaink során többkomponensű rendszerek tulajdonságait javítjuk oly módon, hogy azonosítjuk, majd megváltoztatjuk a domináns tönkremeneteli folyamatot. Jó példa erre a faliszt töltésü polipropilén kompozitok merevségének növelése, ahol a határfelületek elválásának megakadályozásával jelentős merevség növekedést lehet elérni. ${ }^{34,35}$ A vizsgálataink ugyanakkor rámutattak arra a tényre is, hogy a megváltozott határfelületi kölcsönhatások következtében a tönkremenetel mechanizmusa is megváltozik és a szálak szakadása, tördelödése kerül előtérbe. Következésképpen a tulajdonságok csak bizonyos határok között javíthatók. Ilyen összetett mikromechanikai folyamatok jellemző szerkezeteit mutatjuk be az 4. ábrán.
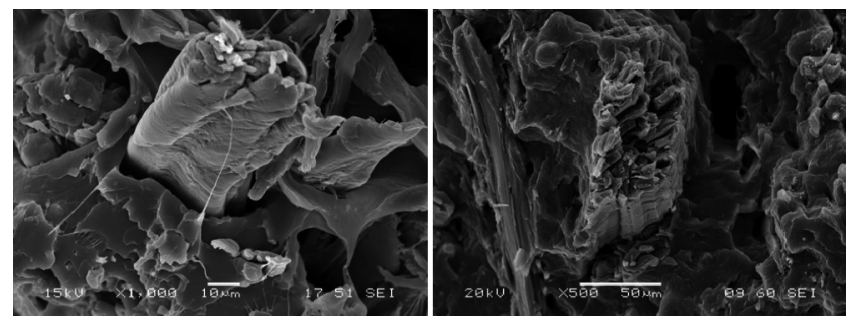

4. ábra: $30 \mathrm{~V} / \mathrm{V} \%$ töltőanyagot és (a) $20 \mathrm{~m} / \mathrm{m} \%$ elasztomer alapú, illetve (b) $10 \mathrm{~m} / \mathrm{m} \%$ elasztomer nélküli funkcionált kapcsolóanyagot tartalmazó kompozit szakított felületéről készített pásztázó elektronmikroszkópos felvétel ((a) - határfelületi elválás és kihúzódás; (b) - száltörés)

Szintén hosszú múltra tekint vissza Laboratóriumunkban a polimer nanokompozitok szerkezet-tulajdonság összefüggéseinek vizsgálata is. A kezdeti ígéretes eredmények ellenére azonban csak kevés esetben valósult meg a nanokompozitok ipari léptékü alkalmazása, esősorban a nanoméretü töltőanyagok nehéz eloszlathatósága miatt. Ennek eredményeképpen az elmúlt években nagyobb hangsúly helyeződött olyan polimer nanokompozitok fejlesztésére, melyek szerkezeti anyagként betöltött szerepükön túl, más egyedi funkcióval is rendelkeznek. Laboratóriumunkban esősorban hallyosittel (HNT), mely egy természetben előforduló, bányászható, csőszerü morfológiával rendelkező ásvány, folynak intenzív kutatások. A csövek hossza néhány száz nanométertől néhány mikrométerig terjed, míg a belső átmérőjük néhány tíz nanométer, ami lehetővé teszi, hogy a cső belsejébe nagyobb méretü molekulák is bejussanak és adszorbeálódhassanak. Kutatásink homlokterében olyan kompozit rendszerek állnak, melyek időben elnyújtva képesek aktív hatóanyag leadására. Ennek fényében tehát olyan HNT/polimer kompozitokat tanulmányoztunk, melyekben különböző stabilizátorokat juttatunk be a HNT csövek belső felületére (5. ábra), hogy időben hosszan elnyújtott stabilizáló hatást érjünk el például poliolefinekben. ${ }^{36,37}$ A töltőanyag jellemzése során, az irodalomban egyedülálló módon, inverz gázkromatográfiával határoztuk meg az ásvány felületi energiáját, aminek döntő szerepe van a kölcsönhatások erősségében. Részletes vizsgálatainkkal bizonyítottuk, hogy az antioxidáns molekulái preferáltan kötődnek meg a nanocsövek belső felületén és az összetétel helyes megválasztása mellett, elnyújtott stabilizáló hatás is biztosítható a módosított nanocsövekkel.

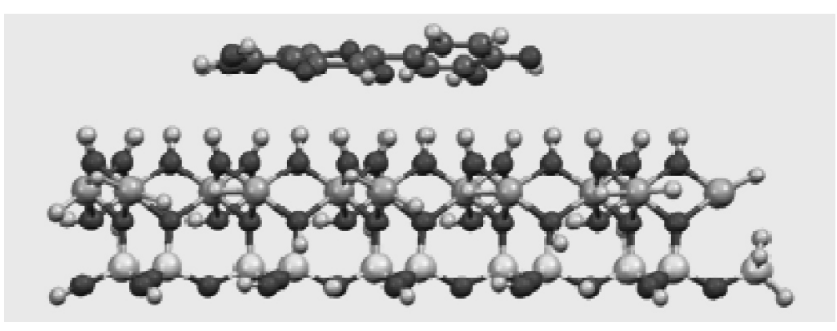

5. ábra: A kvercetin, természetes antioxidáns molekulájának adszorpciója HNT ásvány modellfelületén

Szemikristályos polimerek esetén a tulajdonságok módosíthatók a kristályszerkezet megváltoztatásával is. Erre az ipari gyakorlatban nagy hatékonyságú gócképzőket használnak, melyekkel a felhasználás szempontjából elönyös tulajdonságok, mint a jó átlátszóság, illetve nagy merevség biztosíthatók. A kristályszerkezet célzott módosításával és a polimer molekulaszerkezetének együttes tervezésével tehát olyan tulajdonság kombinációk is elérhetők, melyek egymásnak ellentmondóak. A polipropilén polimorf szerkezetének módosításával olyan rendszert hoztunk létre, ahol a nagy ütésállóságú â-módosulatba kisméretü merev á-módosulatú kristályok képződését idéztük elő önszerveződő módon (6. ábra), így az ütésállóságot duplájára növeltük a merevség csökkenése nélkül. ${ }^{38}$ A gócképző és a polimer molekulaszerkezetének összehangolásával random etilénpropilén kopolimerek ütésállóságát, merevségét és átlátszóságát is nagymértékben növeltük. ${ }^{39}$

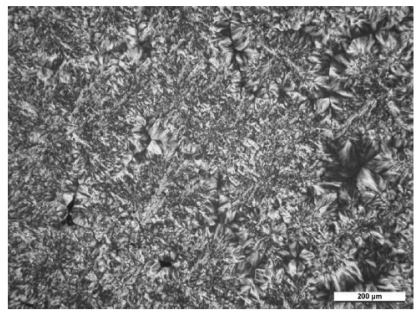

(a)

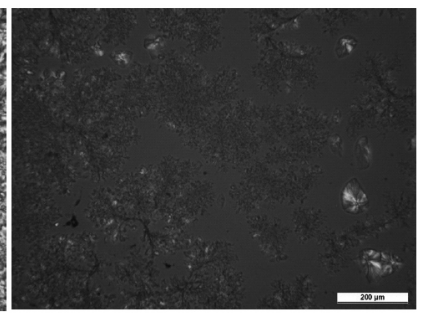

(b)
6. ábra: Polipropilén kristályszerkezete 5000 ppm gócképző jelenlétében: a) végállapot $135^{\circ} \mathrm{C}$-on; b) a â-módosulat részleges kiolvasztását követően $157^{\circ} \mathrm{C}$-on.

A szerkezet-tulajdonság összefüggések mennyiségi leírása és modellezése pedig lehetővé teszi, hogy egyedi tulajdonságok elérhetőségét, illetve az elérésükhöz szükséges szerkezeteket elöre tudjuk jósolni. ${ }^{40}$ Természetesen a kőolajszármazék alapú tömegműanyagok mellett a természetes polimerek kutatása is intenzíven folyik 
Laboratóriumunkban. Keményítő alapú polimerek feldolgozhatóságának javítása napjaink egyik nagy kihívása. A keményítő lágyításával jól feldolgozható faliszt tartalmú biokompozitot állítottunk elő. ${ }^{41}$ A keményítő mellett még cellulóz alapú polimerekkel elsősorban cellulóz nanokristályok funkcionális tulajdonságaival foglalkozunk és a nanocellulóz szuszpenziók egyedi jellegzetességeit tanulmányozzuk. $^{42}$

A hosszú évtizedek óta folytatott témák tapasztalatait természetesen újabb területeken is alkalmazzuk, hiszen a polimerek egyre inkább tért hódítanak az orvosi és biológiai alkalmazások területén is. A hagyományos transzplantációs eljárások hátrányaira például a jövőben a mesterséges szövettenyésztés nyújthat megoldást. A technika három pilléren alapul:

- a regenerálandó szövetet felépíteni képes differenciálatlan sejtek kinyerésén,

- az ezek múködését és szaporodását elősegítő anyagok létrehozásán,

- illetve a kialakítandó szövet támasztását szolgáló vázanyagok elkészítésén.

Ez a váz, vagy más néven scaffold, egy nyitott, összefüggő pórusszerkezettel rendelkező anyag, ami biztosítja, hogy a kialakítandó szövet három dimenzióban növekedhessen. Kulcsfontosságú, hogy a vázon a szövetet kialakító sejtek képesek legyenek megtapadni és elszaporodni, valamint, hogy a vázanyag és bomlástermékei ne legyenek toxikusak a szervezet számára. Pórusos vázanyagok többféle módszerrel is elöállíthatók. Laboratóriumunkban a részecske kioldáson és habosításon alapuló módszerek mellett különböző szálhúzási technikákkal állítunk elő vázanyagokat mesterséges szövettenyésztési célokra. Kutatásaink homlokterében természetes polimerek és szintetikus biopolimerek kombinációjából felépülő vázanyagok szintézise és gyártása áll, ötvözve a kétféle alapanyag típus előnyeit. Sikeresen állítottunk elő mikron- és szubmikron átméröjü szálakból álló vázanyagokat politejsav (PLA), poli-1́-kaprolakton (PCL) és poli-3-hidroxibutirát (PHB), valamint zselatin és kitozán kombinációiból. ${ }^{43}$ Zselatin tartalmú PLA szálak pásztázó elektronmikroszkópos felvétele látható a 7 . ábrán.

Az elektromos szálképzéssel előállított szálak hatóanyag hordozóként is kiválóan alkalmazhatók: gyulladáscsökkentő, és antibakteriális vegyületeket tartalmazó szálakat állítottunk elö dentál-higiéniai felhasználásra, de Candida antarctica, illetve Candida rugosa baktériumokból származó lipáz enzimeket is sikeresen juttattunk politejsav szálakba, amik aztán felgyorsították a polimer bomlási sebességét az emberi szervezetet szimuláló környezetben.

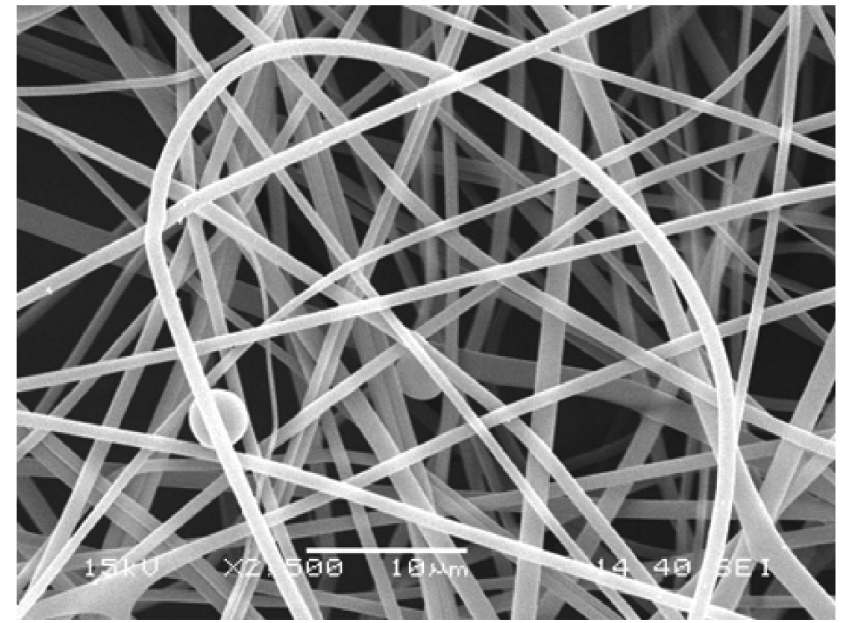

7. ábra: PLA/zselatin alapú elektromos szálképzéssel előállított vázanyag (scaffold)

Laboratóriumunk nem utolsó sorban kiemelt hangsúlyt fektet azokra a polimerekre is, melyek alkalmazási lehetőségei elsősorban a biológiai úton történő lebonthatóságukból fakad. A biológiai úton történő lebonthatóság nem csak a polimer hulladékok komposztálásának, illetve a bioszféra körforgásába történő visszajuttathatóságának szempontjából fontos, hanem számos egészségügyi alkalmazási lehetőség szempontjából is, mert a kívánt polimer az elő szervezetben (In Vivo) kell, hogy lebomoljon. A folyamat modellezése igen összetett probléma, annak ellenére, hogy In Vivo körülmények között a metabolízist katalizáló közeg paramétereinek intervalluma közel állandó $\left(37^{\circ} \mathrm{C}\right.$, és semleges, vagy ahhoz közeli $\left.\mathrm{pH}\right)$. A modellezés célja, hogy meghatározzuk a lebomlás időbeni lefutását, annak érdekében, hogy egy scaffold, vagy egy hatóanyag-hordozó mátrix teljes metabolíziséhez szükséges időt becsülhessük megfelelően megválasztott biokatalizátorok, illetve enzimmolekulák jelenlétében. Laboratóriumunkban több olyan kutatási projekt is folyik, melyek célja az orvosbiológiában ma már elterjedten alkalmazott mikrobiális poliészterek (például poli(3-hidroxibutirát), PHB) enzimkatalizált metabolízisének jellemzése, illetve az enzimreakció kinetikájának mennyiségi leírása. Az utóbbi években sikerrel fejlesztettünk ki és alkalmazunk olyan kinetikai modelleket, melyekkel nem csak a mikrobiális poliészterek lebomlásának leírása, de egyben a reakció lefutásának illetve időfüggésének becslésére, jóslására is lehetőség nyílik. ${ }^{44}$ 


\section{Hivatkozások}

1. Manek, E.; Berke, B.; Miklósi, N.; Sajbán, M.; Domán, A.; Fukuda, T.; Czakkel, O.; László, K. Express Polymer Letters 2016, 10, 710-720.

https://doi.org/10.3144/expresspolymlett.2016.64

2. Tóth, A.; Voitko, K.V.; Bakalinska, O.; Prykhod'ko, G.P.; Bertóti, I.; Gun'ko, V.M.; László, K. Carbon 2012, 50, 577-585. https://doi.org/10.1016/j.carbon.2011.09.016

3. Wang, S.; Ábrahám, D.; Vallejos-Burgos, F.; Geissler, E.; László, K.; Takeuchi, K.; Endo, M.; Kaneko, K. Langmuir 2016, 32, 5617-5622.

https://doi.org/10.1021/acs.langmuir.6b00483

4. Czakkel, O.; Marthi, K.; Geissler, E.; László, K. Micropor. Mesopor. Mater. 2005, 86, 124-133.

https://doi.org/10.1016/j.micromeso.2005.07.021

5. Domán, A.; Madarász, J.; László, K. Thermochim. Acta 2017, 647, 62-69. https://doi.org/10.1016/j.tca.2016.11.013

6. Pekala, R.W.J Mater Sci. 1989, 24, 3221-3227. https://doi.org/10.1007/BF01139044

7. Nagy, B.; Ábrahám, D.; Dobos, G.; Madarász, J.; Onyestyák, Gy.; Sáfrán, Gy.; Geissler, E.; László, K. Carbon 2014, 66, 210-218.

https://doi.org/10.1016/j.carbon.2013.08.060

8. Seredych, M.; László, K.; Bandosz, T.J. Chem Cat Chem 2015, 7 (Special Issue: SI) 2924-2931.

https://doi.org/10.1002/cctc.201500192

9. Nagy, B.; Villar-Rodil, S.; Tascón, J.M.D.; Bakos, I.; László, K. Micropor. Mesopor. Mater. 2016 ,230, 135-144. https://doi.org/10.1016/j.micromeso.2016.05.009

10. Bahn, E.; Czakkel, O.; Nagy, B.; László, K.;Villar-Rodil, S.; Tascón, J.M.D.; Demmel, F.; Telling, M.T.F.; Fouquet, P. Carbon 2016, 98, 572-581. https://doi.org/10.1016/j.carbon.2015.11.034

11. Tardy, G.M.; Lóránt, B.; Lóka, M.; Nagy, B.; László, K. Biotechnol. Lett. 2017, 39, 993-999. https://doi.org/10.1007/s10529-017-2338-x

12. Albert, E. Mezopórusos szol-gél bevonatok: elöállitás, jellemzés, alkalmazás, PhD értekezés, Budapesti Müszaki és Gazdaságtudományi Egyetem, 2015.

13. Albert, E.; Hórvölgyi, Z. Mezopórusos szol-gél bevonatok: előállítás, jellemzés ( $\mathrm{PhD}$ összefoglaló), alkalmazás Magyar Kémiai Folyóirat 2017, közlésre elfogadva

14. Albert, E.; Albouy, P. A.; Ayral, A.; Basa, P.; Csík, G.; Nagy, N.; Roualdčs, S.; Rouessac, V.; Sáfrán, Gy.; Suhajda, Á.; Zolnai, Zs.; Hórvölgyi, Z. RSC Adv. 2015, 5, 59070-59081. https://doi.org/10.1039/C5RA05990A

15. Albert, E.; Cotolan, N.; Nagy, N.; Sáfrán, Gy.; Szabó, G.; Mureşan, L. M.; Hórvölgyi, Z. Micropor. Mesopor. Mat. 2015, 206, 102-113. https://doi.org/10.1016/j.micromeso.2014.12.021

16. Volentiru, E.; Nyári, M.; Szabó, G.; Hórvölgyi, Z.; Mureşan, L. M. Period. Polytech. Chem. 2014, 58, 61-66. https://doi.org/10.3311/PPch.7302

17. Kócs, L.; Albert, E.; Tegze, B.; Kabai-Faix, M.; Major, Cs.; Szalai, A. ; Basa, P. ; Hórvölgyi, Z. Period. Polytech. Chem. 2017, közlésre elfogadva DOI: 10.3311/PPch.10550https://doi.org/10.3311/PPch.10550

18. Dabóczi, M.; Albert, E.; Agócs, E.; Kabai-Faix, M.; Hórvölgyi, Z. Carbohyd. Polym. 2016, 136, 137-145. https://doi.org/10.1016/j.carbpol.2015.09.025

19. Németh, C.; Szabó, D.; Gyarmati, B.; Gerasimov, A.; Varfolomeev, M.; Abdullin, T.; László, K.; Szilágyi A. Eur. Polym. J. 2017, 93, 805-814.

https://doi.org/10.1016/j.eurpolymj.2017.02.024
20. Krisch, E.; Messager, L.; Gyarmati, B.; Ravaine, V.; Szilágyi, A. Macromol. Mater. Eng. 2016, 301, 260-266. https://doi.org/10.1002/mame.201500119

21. Gyarmati, B.; Mészár, E.Z.; Kiss, L.; Deli, M.A.; László, K.; Szilágyi, A. Acta Biomater. 2015, 22, 32-38. https://doi.org/10.1016/j.actbio.2015.04.033

22. Gyarmati, B.; Vajna, B.; Némethy, Á.; László, K.; Szilágyi A. Macromol. Biosci. 2013, 13, 633-640. https://doi.org/10.1002/mabi.201200420

23. Pál, K., Kállay, M., Köhler, G., Zhang, H., Bitter, I., Kubinyi, M., Vidóczy, T., Grabner, G., ChemPhysChem, 2007, 8, $2627-2635$. https://doi.org/10.1002/cphc.200700479

24. Grofcsik, A., Kubinyi, M., Jones, W. J., Chem. Phys. Lett., 1996, 250, 261-265. https://doi.org/10.1016/0009-2614(96)00003-6

25. Hessz, D., Hégely, B., Kaěllay, M., Vidoěczy, T., Kubinyi, M., J. Phys. Chem. A, 2014, 114, 5238-5247. https://doi.org/10.1021/jp504496k

26. Kubinyi, M., Vidóczy, T, Varga, O., Nagy, K., Bitter, I., Appl. Spectrosc., 2005, 59, 134-138. https://doi.org/10.1366/0003702052940477

27. Varga, O., Kubinyi, M., Vidóczy, T., Baranyai, P., Bitter, I., Kállay, M., J. Photochem. Photobiol. A, 2009, 207, 167-172. https://doi.org/10.1016/j.jphotochem.2009.07.001

28. Bojtár, M., Szakács, Z., Hessz, D., Kubinyi, M., Bitter, I., RSC Adv., 2015, 5, 26504-26508. https://doi.org/10.1039/C4RA14809F

29. Bojtár, M., Paudics, A., Hessz, D., Kubinyi, M., Bitter, I., RSC Adv. 2016, 6, 86269-86275. https://doi.org/10.1039/C6RA15003A

30. Bojtár, M., Kozma, J., Szakács, Z., Hessz, D., Kubinyi, M., Bitter, I., Sens. Actuat. B, 2017, 248, 305-310. https://doi.org/10.1016/j.snb.2017.03.163

31. Kubinyi, M., Pál, K., Baranyai, P., Grofcsik, A., Bitter, I., Grün. A., Chirality, 2004, 16, 174-179. https://doi.org/10.1002/chir.20003

32. Costero, A. M., Colera, M., Gavia, G., Gil, S., Kubinyi, M., Pál, K., Kállay, M., Tetrahedron, 2008, 64, 3217-3224. https://doi.org/10.1016/j.tet.2008.01.085

33. Rapi, Z, Bakó, P., Keglevich, G., Baranyai, P, Kubinyi, M., Varga, O., J. Incl. Phenom. Macrocycl. Chem., 2014, 80, 253-261. https://doi.org/10.1007/s10847-014-0384-8

34. Sudár, A., Renner, K., Móczó, J., Lummerstorfer, T., Burgstaller, C., Jerabek, M., Gahleitner, M., Doshev, P., Pukánszky, B. Compos. Struct., 2017, 141. 146-154. https://doi.org/10.1016/j.compstruct.2016.01.031

35. Sudár, A., Burgstaller, C., Renner, K., Móczó, J., Pukánszky, B. Compos. Sci. Technol., 2014, 103, 106-112. https://doi.org/10.1016/j.compscitech.2014.08.018

36. Hári, J., Gyürki, Á., Sárközi, M., Földes, E., Pukánszky, B. J. Colloid Interface Sci, 2016,. 462, 123-129. https://doi.org/10.1016/j.jcis.2015.09.054

37. Hári, J., Polyák, P., Mester, D., Mičušík, M., Omastová, M., Kállay, M., Pukánszky, B. Appl. Clay Sci., 2016, 132, 167-174. https://doi.org/10.1016/j.clay.2016.06.001

38. Horváth, F., Gombár, T., Varga, J., Menyhárd, A. J. Therm. Anal. Calorim., 2017, 128, 925-935. https://doi.org/10.1007/s10973-016-6057-7

39. Horváth, Z., Menyhárd, A., Doshev, P., Gahleitner, M., Friel, D., Varga, J., Pukánszky, B. J. Appl. Polym. Sci., 2016 133, 43823. https://doi.org/10.1002/app.43823

40. Menyhárd, A., Suba, P., László, Z., Fekete, H. M., Mester, Á. O., Horváth, Z., Vörös, G., Varga, J., Móczó, J. Express Polym. Lett., 2015, 9, 308-320. https://doi.org/10.3144/expresspolymlett.2015.28 
41. Müller, P., Renner, K., Móczó, J., Fekete, E., Pukánszky, B. Carbohydr. Polym., 2014, 102, 821-829. https://doi.org/10.1016/j.carbpol.2013.10.083

42. Csiszár, E., Kalic, P., Köböl, Á., Ferreira, E. D. Ultrason. Sonochem., 2016, 31, 473-480.

https://doi.org/10.1016/j.ultsonch.2016.01.028
43. Nagy, O.; Kirschweng, B.; Imre, B.; Pukánszky, B. Müanyag és Gumiipari Évkönyv, 2016, 14, 46-53.

44. Kirschweng, B.; Polyák, P.; Pukánszky, B.; Vörös, G. Polimerek, 2015, 1, 136-140.

\section{Research activity at the Department of Physical Chemistry and Materials Science}

The R\&I activity of the Surface Chemistry Group has been focusing on interactions with high surface area solid materials, spanning from the various forms of crystalline nanocarbons (nanotubes, graphene and their derivatives) to the new generation of porous materials like carbon aerogels or metal-organic frameworks (MOFs). The tunability of the morphology as well as the surface chemistry of these materials, important factors in their practical performance, are studied in the group. Tailor-made novel materials and their composites have been synthesized, characterized and tested for biomedical, gas and energy storage applications.

In the Colloid Chemistry Group different types of sol-gel and biopolymer thin coatings with various functional properties were deposited by dip-coating onto solid substrates. Semiconductor $\left(\mathrm{TiO}_{2}, \mathrm{ZnO}\right)$ coatings with antibacterial and photoactive properties, mesoporous $\mathrm{SiO}_{2}$ coatings with improved light transmittance and anticorrosive properties, biopolymer and biopolymer-mesoporous $\mathrm{SiO}_{2}$ sol-gel composite coatings for modelling controlled drug release systems were developed and characterized thoroughly.

The research activity of Soft Matters Group focuses on the synthesis, characterization and application of responsive polymers and hydrogels. These smart materials are prepared in various forms such as water-swellable gels, in situ gellable, bioadhesive polymer solutions or polymer films and they are designed for pharmaceutical applications, primarily in controlled and targeted drug delivery. Recently, our research work has been extended with such cutting-edge technologies as electrospinning and 3D printing to develop responsive materials with tailor-made morphology.

The target of our research in the Spectroscopy Group is to develop novel molecular sensors, applicable in fluorescence imaging techniques. In a co-operation with the synthetic chemists of our university, novel fluorescent chemosensors have been developed for the detection of amino acids, biogen amines and nucleotides. The sensing mechanisms of the fluorescent probes have been explored on the basis of time-resolved optical spectroscopic experiments and theoretical calculations.
The Laboratory of Plastics and Rubber Technology (LPRT, former an individual department) as a part of the Department Physical Chemistry and Materials Science was established in 1953. Its primary goal is to educate professionals, who are experienced in the synthesis and processing of polymeric materials and these goals are constant even nowadays. LPRT forms a professional research group together with the Polymer Physics Group at the Research Centre for Natural Sciences at Hungarian Academy of Sciences. Intensive research has been carrying out on the field of multicomponent polymer systems in the past three decades. Most of these studies are dealing with the interfacial interactions as well as the mechanism of the failure of composite materials. A special technique called acoustic emission is used for identification of failure mechanism in order to find possible ways to improve strength and impact resistance mainly. The study of crystalline polymer has large tradition at our Laboratory as well. Recently the development of quantitative correlation between the crystalline structure and the mechanical or optical properties is in the focus of these works. Our goal is to build empirical or semi-empirical models to describe the dependency of tensile modulus or haze on the key parameters of crystalline structure. After the careful validation of these models they are used to predict desired properties in order to define possible directions during industrial development projects. Although, these researches are focused mainly on commodity polymers the results obtained from them could be applied on other areas as well. An intensive research is focused on the preparation of scaffold materials as possible templates for ectogenesis, which is a hot topic in the medial application of polymeric materials. Beside medical application the bio based polymers are also important candidates for biocompatible and biodegradable materials. These topics are also a highlighted areas at or Laboratory. The kinetics and detailed characteristics of microbial synthesis and biodegradation process (even In Vivo) of poly-3-hydroxybutirate is studied thoroughly for example in this field. 